\title{
甲状腺内上皮小体癌例
}

\author{
楯谷 智子1) ・ 北村 溥之 之 $^{2)} \cdot$ 庄司 和彦1) ・ 高北 晋一1) \\ 岩橋 由佳 3 - 河田 恭孝 1$) \cdot$ 宮崎 眞和 4 )
}

\section{A Case of Intrathyroidal Parathyroid Carcinoma}

\author{
Tomoko Tateya, Kazuhiko Shoji, Shin-ichi Takagita and Yasutaka Kawata \\ (Tenri Hospital)
}

Hiroyuki Kitamura

(Takai Hospital)

Yuka Iwahashi

(Shimane Prefectural Central Hospital)

Masakazu Miyazaki

(National Cancer Center Hospital East)

\begin{abstract}
Intrathyroidal parathyroid carcinoma is very rare. To our knowledge, only 2 cases of intrathyroidal parathyroid carcinoma had been reported in Japan. Recently, we encountered a case of hyperfunctioning intrathyroidal parathyroid carcinoma.

A 16-year-old female had complained of thirst, polyposia and polyuria for 6 months. An elastic hard nodule $2 \mathrm{~cm}$ in diameter was palpated on the right thyroid lobe. The serum calcium level was $16.2 \mathrm{mg} /$ $\mathrm{dl}$ and serum intact-PTH level was $1100 \mathrm{pg} / \mathrm{ml}$ (normal value in serum: $10 \sim 60 \mathrm{pg} / \mathrm{ml}$ ). Based on ultrasonography and ${ }^{201} \mathrm{Tl}$ subtraction ${ }^{99 \mathrm{~m}} \mathrm{Tc}$ scanning, primary hyperparathyroidism due to a hyperfunctioning parathyroid gland in the right thyroid lobe was suspected. A right lobectomy and local dissection was performed. The tumor was histologically diagnosed as an intrathyroidal parathyroid carcinoma. The patient was asymptomatic and normocalcemic 29 months after surgery.
\end{abstract}

Key words : parathyroid carcinoma, intrathyroidal parathyroid, primary hyperparathyroidism

はじめに

原発性上皮小体機能宇進症（PHPT）を起こす疾患の なかで上皮小体癌はまれな疾患であり, 本邦で PHPT の 診断で手術を施行された症例の $2 \%$ に過ぎない1).また， 本邦 PHPT 手術症例のうち異所性上皮小体病変による PHPT は $5 \%$, 甲状腺内上皮小体病変に限ると $2 \%$ であ

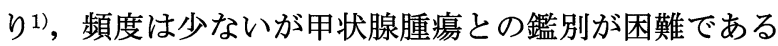
ことがあり，注意を要する2)。最近われわれは PHPT を

1) 天理よろづ相談所病院耳鼻咽喉科

3）島根県立中央病院耳鼻咽喉科
示す非常にまれな甲状腺内上皮小体癌を経験したので， 文献的考察を加え報告する.

\section{症例}

症例 : 16 歳, 女性.

主訴: 口渴, 多飲, 多尿.

既往歷：12 歳時に紫班病性腎炎。

家族歴：父親に糖尿病.
2) 高井病院耳鼻咽喉科

4）国立がんセンター東病院頭頸科 


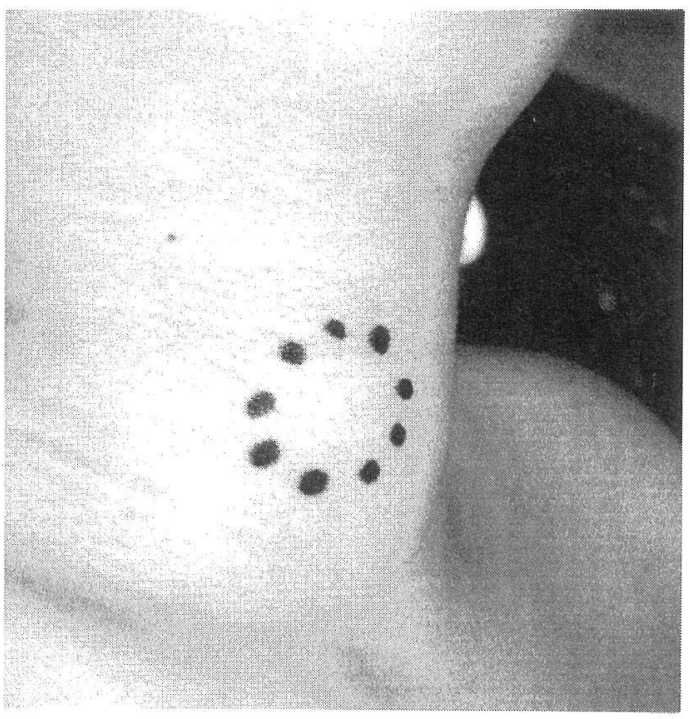

図 1 靧部所見

現病歴：約半年間持続する口渴, 多飲, 多尿があり, また便秘，全身倦怠感もあった。平成 11 年 11 月 15 日に 天理よろづ相談所病院内分泌内科を受診した。血清力ル シウム $16.2 \mathrm{mg} / \mathrm{dl}$ と異常高值を認めたため, 精査および 高カルシウム血症の治療のため入院となった。

局所所見：甲状腺右葉に径 $2 \mathrm{~cm}$ の弾性硬，表面平滑， 可動性ある腫瘤を触知した（図 1)。頸部リンパ節腫大は なく，声帯麻痺は認めなかった。

検查所見: 血液検查で Ca $16.2 \mathrm{mg} / \mathrm{dl}$, free Ca $2.3 \mathrm{mmol}$, intact-PTH $1100 \mathrm{pg} / \mathrm{ml}$ （基準值 $10 \sim 60 \mathrm{pg} / \mathrm{ml}$ ），ALP

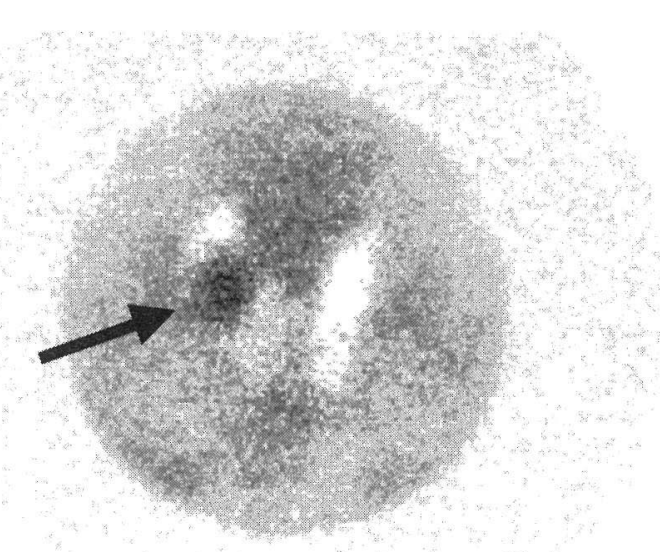

図 $2{ }^{201} \mathrm{Tl}{ }^{99 m} \mathrm{Tc}$ サブトラクションシンチグラフィ 甲状腺右葉に集積を認めた (矢印)。

16360IU（ほぼすべて ALP3 の骨型）と異常高值を示して いたため，PHPT と診断し，上皮小体病変の局在診断お よび多発性内分泌腫場の有無の精査を行った。

${ }^{201} \mathrm{~T} 199 \mathrm{~m} \mathrm{Tc}$ サブトラクションシンチグラフィで甲状腺右 葉に集積を認めた（図 2)。頸部エコーでは，甲状腺右葉 内に境界明瞭な低エコー腫瘤を認めた（図 3). 腫大した 上皮小体を疑わせる病変は，甲状腺背側の通常の位置に は描出されなかった。以上より甲状腺右葉内の異所性上 皮小体腫瘍による PHPT を疑った。なお，頸部 CT・MRI は行っていない。

頭部 MRI および腹部エコーで下垂体，脺，副腎に内分 泌腫瘍を疑わせる腫瘤性病変を認めず，下垂体ホルモン，

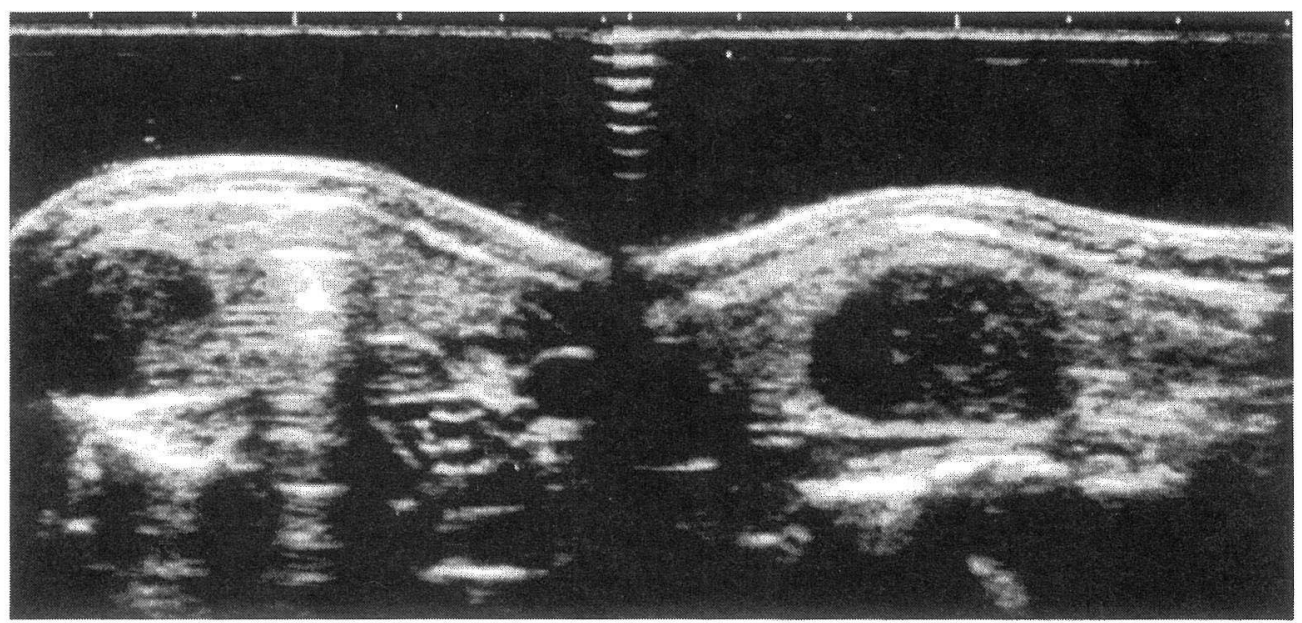

図 3 頸部エコー所見（左：横断像，右：縦断像） 
血中および尿中カテコラミン值，CEA，カルシトニンは 正常であり，多発性内分泌腫瘍は否定的であった。

高カルシウム血症の治療：生理食塩水 $3000 \mathrm{ml}$ 前後 / 日，プレドニン $40 \mathrm{mg} /$ 日を 8 日間点滴したが，血清カル シウム值は $14.2 \mathrm{mg} / \mathrm{d} 1$ 以下には下がらず依然として高值 であった。

平成 11 年 12 月 2 日当科にて全身麻酔下に甲状腺右葉 切除術を施行した。

術中所見：甲状腺右葉上極に腫瘤があり，右葉下極背 側に上皮小体下腺と思われる腫溜があった（図 4).甲状 腺右葉を上皮小体下腺と思われる腫瘤とともに切除し た。周囲組織に癒着は認められなかった。右反回神経は 確認保存した。術中迅速病理では, 甲状腺右葉上極の腫 瘤は䯣様癌の疑いという診断であり, 右葉下極背側の腫 瘤は上皮小体組織という診断であった。甲状腺髄様癌と 右上皮小体下腺腫瘍による PHPT の合併と考えた。䯣様 癌の確定診断がつけばRET遺伝子の検索等を行って甲状 腺全摘の適応を考虑することにし, D1 郭清のみ追加して 手術を終了した。手術終了時血清カルシウム值は $12.7 \mathrm{mg} / \mathrm{dl}$ まで下がっていた。気管周囲・甲状腺周囲に リンパ節腫大は認められなかった。

摘出標本 : 甲状腺右葉の腫瘍は $20 \times 20 \times 18 \mathrm{~mm}$, 黒 褐色の囊胞液を伴い，割面は黄褐色であった（図 5)。ま た, 甲状腺被膜外の下極よりに $10 \times 6 \times 4 \mathrm{~mm} の$ 上皮小 体を認めた。

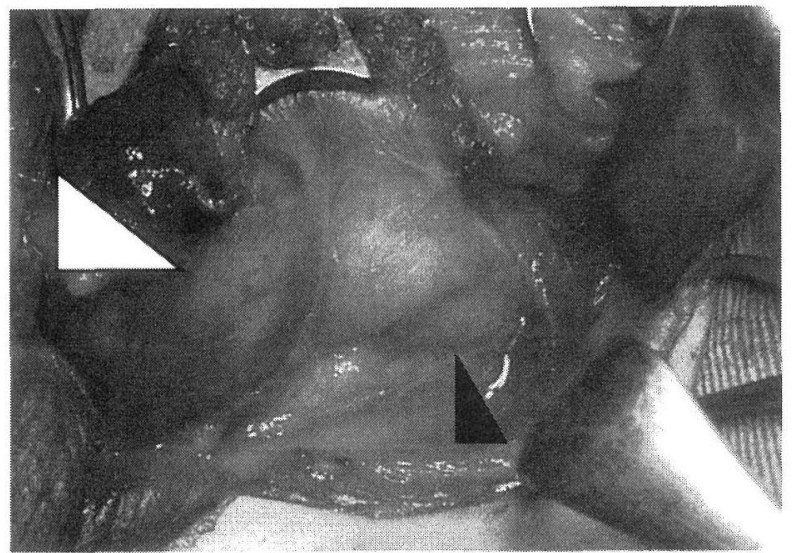

図 4 術中所見

左が頭側，上が左側であり，甲状腺を翻転させ甲状腺背 側をみている. 甲状腺右葉上極江腫瘤 (白い三角)，右葉 下極背側に上皮小体と思われる腫瘤（黑い三角）を認ぬ た.

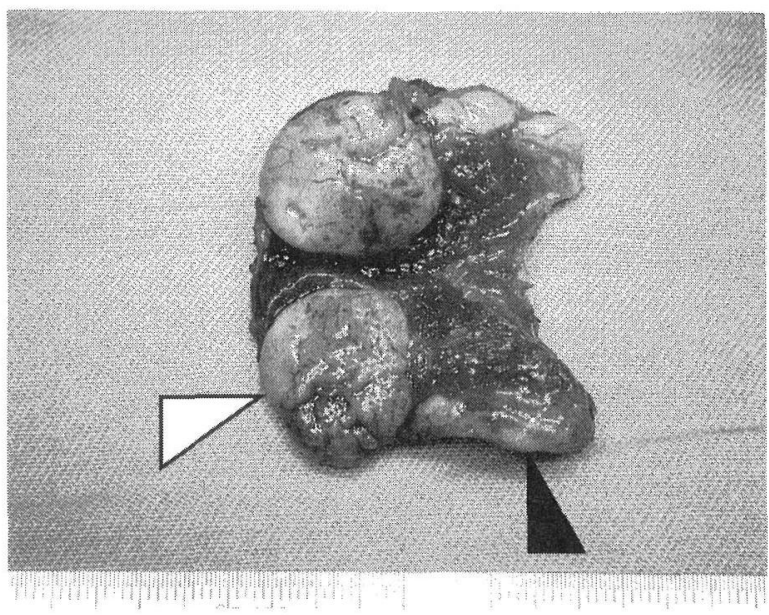

図 5 摘出標本

割面を示す．左が頭側．甲状腺右葉上極内に径 $20 \mathrm{~mm}$ の 腫瘍があり (白い三角)，甲状腺下極の被膜外に上皮小体 を認めた (黒い三角)。

病理組織所見：右上皮小体下腺は正常の上皮小体組織 であった。甲状腺右葉の腫瘍は，カルシトニン，サイロ グロブリンなどの特殊染色で染まらず，髄様癌などの甲 状腺腫瘍は否定的であった。異型の強い腫瘍細胞が索状 およびパリセード状の腫瘍細胞の増殖を示し, 被膜侵襲, 血管侵襲は認められなかったが，核分裂像が非常に多く みられ強拡大で 3 個認められる部分もあり，細胞增殖因 子 Ki-67（多いほざ悪性を示唆する）で標識される細胞 も非常に多加た（図 6)。

以上の病理組織学的所見と臨床経過より，上皮小体癌 と診断した。

術後経過: 血清カルシウム值は術翌日には $10.4 \mathrm{mg} / \mathrm{dl}$, 術後 1 週間後には $7.1 \mathrm{mg} / \mathrm{dl}$ まで低下した。 intact-PTH は術翌日に基準值以下にまで低下した。著しい飢餓骨症 候群を呈し，術後 7カ月間カルシウムとビタミン D 補充 が必要であった。

intact-PTHは術後3カ月目より再び上昇し始め, $160 \mathrm{pg} /$ $\mathrm{ml}$ 前後の高值を維持した後, 術後 16 力月で正常化した。 その間血清カルシウムはずっと正常值であり，また全身 検索の結果再発病巣は認められなかった。術後 2 年 5 カ 月現在，血清カルシウム值は正常であり再発は認めてい ない。

考 按

第 34 回甲状腺外科研究会（2001 年，東京）における 

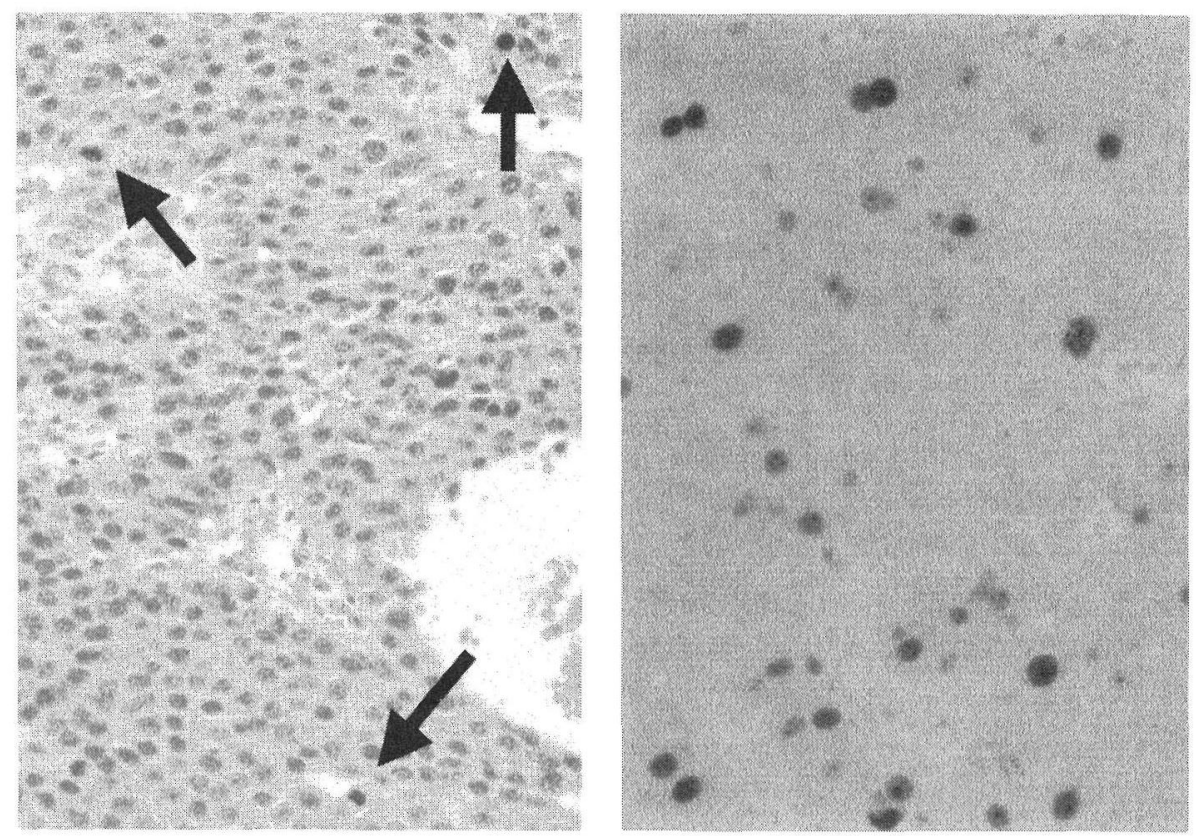

図 6 病理組織所見 $(\times 80)$

左：HE 染色. 矢印は核分裂像を示す。

右：免疫染色 (Ki-67). 核分裂中の細胞が標識されている.

最近 10 年間の全国 PHPT 手術症例 3152 例の調查結果報 告 ${ }^{1)}$ によると，上皮小体病変の頻度は腺腫 2718 例（86 $\%)$ ，過形成 340 例（11\%）に比し，癌は 52 例 $(2 \%)$ と まれであった。また異所性上皮小体病変は 147 例（5\%） と少数であり, その内訳は縦隔内 75 例, 甲状腺内 54 例, 下行不全 11 例, その他 7 例であった。

甲状腺内上皮小体癌は大変まれな疾患であり，本邦に おける甲状腺内上皮小体癌の症例報告は渉猟し得た限り 2 例のみであった ${ }^{344)}$.

登5) は剖検例による甲状腺内上皮小体を $1.8 \%$ と報告 している。なぜ上皮小体が甲状腺内に埋没するのかはよ くわかっていないが，胎生期に第 4 鰓囊の上皮成分から 甲状腺構成成分が生じる際に，同じ第 4 鰓囊から発生分 化する上皮小体組織が甲状腺内に埋没するという説 6) と，甲状腺内上皮小体は第 3 鰓囊由来の下上皮小体であ るといら説7がある。

上皮小体癌は上皮小体腺腫や過形成などの良性病変に 比べ, PHPT の臨床症状が激しいことが知られており, $14 \mathrm{mg} / \mathrm{dl}$ 以上の血清カルシウム值を示し, 骨病変, 膆炎, 消化性潰瘍，高カルシウム血症クリーゼなどをきたすこ とが多いとされる。また，上皮小体良性病変に比べ腫瘤
が硬くて大きく，術前に触知されることが多い8)。また PTH の測定值は, 各施設ごとに正常值が異なり比較が難 しいが，上皮小体癌の多くは異常高值を示すといら9)10). 岡本ら9) は上皮小体腫瘍の術前情報を検討し, 癌を予測 する所見として頸部腫瘤触知は鋭敏度 $(0.995)$ が高く, 血中 C-PTH 值が正常上限 10 倍以上であることは特異度 （0.787）が最も高いと述べている。本症例も， $16.2 \mathrm{mg} /$ $\mathrm{dl}$ という著しい高カルシウム血症, 正常上限18倍のintactPTH 值, 頸部腫瘤の触知といら上皮小体癌の臨床的特徴 を備えており，術前に上皮小体癌の可能性を予測するこ とは可能であった。

上皮小体腫瘍の病理組織診断は難しいことで知られて いるが，本症例の病理組織診断において困難な点が $2 つ$ あった。一つには，甲状腺内に存在したため，術中迅速 病理で髄様癌と診断されてしまい，混乱をきたしたこと が挙げられる.上皮小体腫瘍は病理組織学的には甲状腺, 胸腺などの腫煬との鑑別が困難なことがあり ${ }^{10)}$, 坂本ら ${ }^{21}$ は術中迅速病理で甲状腺滤胞癌と診断された上皮小体腫 瘍症例を報告している。また髄様癌もほかの内分泌腫瘍 や肺の小細胞未分化癌に類似し，アミロイドの存在やカ ルシトニンなどの特殊染色で鑑別されるので ${ }^{11)}$ ，迅速凍 
結標本のみでは上皮小体癌との鑑別は困難である，本症 例では術中迅速診断の際に, 甲状腺内の異所性上皮小体 病変によるPHPT の可能性が高いということを病理医に 伝えておらず，病理医が甲状腺腫瘍として診断をつけよ うとし，また若年例であり PHPT と甲状腺腫瘍の存在か ら多発性内分泌腫瘍が連想されやすかったために，術中 には髄様癌と上皮小体病変の合併という診断になった。 術中迅速診断にあたっては臨床所見を十分に病理医に伝 える必要があったと反省している。

もう一つの問題点は, 上皮小体癌の病理組織学的診断 基準はまだ必ずしも確立されていないので，転移や局所 浸潤があるものは容易に癌と診断がつくが，そうでない ものは病理組織学的に上皮小体癌と確定診断するのが難 しいことである ${ }^{8)}$. Schantz $~^{12)}$ は，上皮小体癌の病理組 織学的特徴として（1）厚い線維性被膜と結合織梁の形 成，(2) パリセード状および索状の腫揚細胞の増殖，(3) 腫瘍細胞の核分裂像，（4）被膜侵襲あるいは血管侵襲の 4 つの所見を挙げている. 特に腫盷細胞の核分裂像を最 も信頼性のある診断根拠として強調している. この Schantz ら ${ }^{12)}$ のいら病理診断基準が最も妥当なむのとし て一般に認められているが，この項目をどこまで満たせ ば癌の確定診断をつけてよいのか確定しておらず ${ }^{8) ， ま ~}$ た実際にはこれらの所見に乏しく病理組織学的に癌と診 断することが困難な症例で，再発または転移が発見され て初めて癌の診断が下されることもある ${ }^{13) 144}$ ．本症例は

（2）（3）を満たし，特に（3）の腫瘍細胞の核分裂像が著 明であることから, 臨床所見す踏まえて癌と診断した。

上皮小体癌の治療は外科的摘出が基本であり, 再発す ると根治的摘出が困難になるため隣接臟器を含めen bloc 摘除を行うことが肝要であるといわれる8). リンパ節転 移が初回手術時にみられることはまれであり，明らかな 転移を認める症例のみ根治的頸部郭清を行うのがよいと されるが ${ }^{12)}$ ，局所浸潤の激しい症例では念のためリンパ 節郭清を追加すべきという意見もある13114)。本症例は腫 瘍を含めた甲状腺右葉切除と局所郭清が施行されてお り，初回治療としては妥当な術式であったと考える.

本症例では術後経過観察中に, 術後 3力月目より血清 カルシウムが正常値のまま intact-PTH 值が上昇し始め, $160 \mathrm{pg} / \mathrm{ml}$ 前後の高値を維持した後, 術後 16 カ月で正常 化するという特異な経過をたどった。術前に intact-PTH 值が高値であり激しい PHPT 症状を示した症例は, 術後 血清カルシウムが正常値のまま intact-PTH 值が上昇する
ことがあり，再発ではなくカルシウム代謝にかかわる内 分泌学的な機序によるものであることを示唆する報告が ある ${ }^{15) 16)}$. そのため, 術後の経過観察において再発の指 標としては血清カルシウム值が最適であり, 血清カルシ ウムが正常值であれば intact-PTH 值が上昇しても問題は ないと考えられる。

石田ら 17) の全国集計では上皮小体癌の術後再発率は 34. $4 \%$ であった. 上皮小体癌は増殖傾向の緩除なものが 多いとされ，初回手術から初めの再発までの期間は平均 3 年5) といわれるが，早いものでは 3 週間，遅いもので は 10 年以上 ${ }^{18)}$ と再発までの期間に広い幅がある. 本症 例は 2 年以上経過したが, 長期にわたり注意深く経過観 察することが必要と考える.

\section{まとめ}

原発性上皮小体機能克進症（PHPT）を示す甲状腺内 上皮小体癌を経験した. 症例は 16 歳女性であり, 約半年 間持続する口渴, 多飲, 多㲾があった. 弾性硬の前頸部 腫瘤を触知し, 血清カルシウム $16.2 \mathrm{mg} / \mathrm{dl}$, intact-PTH は正常上限 18 倍と異常高値を示した. 甲状腺右葉切除 術, D1 郭清術を施行し, 術後上皮小体癌と診断した。本 邦における甲状腺内上皮小体癌の報告はこれまで 2 例で あり，非常にまれな症例と考えられた。

本論文の要旨は第 62 回耳鼻咽喉科臨床学会 $(2000$ 年 7 月 8 日，福井市）にて口演した.

\section{参考文献}

1）小原孝男：甲状腺髄様癌の現状と予防・早期発見. 原発性 副甲状腺機能充進症の現状 (当番世話人報告). 第 34 回甲 状腺外科研究会, 2001 .

2）坂本 守，木谷真理，上地陽子：上皮小体腫瘍の 2 症例一 困難であった甲状腺腫瘍との鑑別一.耳鼻臨床 $90: 219$ 226, 1997.

3）八代 享, 河野通一, 山下共行, 他: 初回手術時に見つか らず, 2 年 6 力月後に摘除に成功した甲状腺内上皮小体癌の 1例. 木と臨床 $34: 256 \sim 259,1986$.

4）江波戸久之, 太田利雄, 石毛則男, 他 : 甲状腺内に存在し た副甲状腺癌の一例. 日本臨床細胞学会会誌 32:254, 1993.

5）登 政和：上皮小体の外科解剖. 外科診療 $29: 147 \sim 155$, 1987.

6) Wang $C$ : Hyperfunctioning intrathyroid parathyroid gland; a potential cause of failure in parathyroid surgery. J R Soc Med $74: 49 \sim 52,1981$. 
7) Bainbridge ET and Barnes AD : Primary hyperparathyroidism due to overactive intrathyroid parathyroid glands; a potential cause of failed exploration. Br J Surg $69: 200 \sim 202,1982$.

8）小原孝男, 藤本吉秀: 上皮小体の外科一上皮小体癌一. 内 分泌外科 $1: 179 \sim 187,1984$.

9）岡本高宏, 小原孝男, 藤本吉秀, 他：上皮小体癌の術前診 断一術前情報の量的評価一. 内分泌外科 8:401 405, 1991 .

10) Holmes EC, Morton DL and Ketcham AS : Parathyroid carcinoma; a collective review. Ann Surg $169: 631 \sim 640,1969$.

11）齊藤 脩, 岡田博允, 市川銀一郎 : 7. 4. 頸部の腫瘤性病変. 病理カラーアトラス 耳鼻咽喉科領域の病理. $270 \sim 293$ 頁, 杏林書院，東京，1992.

12) Schantz A and Castleman B : Parathyroid carcinoma; a study of 70 cases. Cancer $31: 600 \sim 605,1973$.

13）小原孝男, 藤本吉秀, 伊藤悠基夫, 他：原発性上皮小体機 能古進症一上皮小体癌の診断と治療方針一. 外科診療 29 : $171 \sim 177,1987$.

14）植松正久, 岡田昌義, 久野克也：副甲状腺癌の 8 例. 日臨 外 $60: 1767 \sim 1776,1999$.
15) Mandal AK and Udelsman $R$ : Secondary hyperparathyroidism is an expected consequence of parathyroidectomy for primary hyperparathyroidism; a prospective study. Surgery $124: 1021$ 〜 1027, 1998.

16) Westerdahl J, Valdemarsson S, Lindblom P, et al. : Postoperative elevated serum levels of intact parathyroid hormone after surgery for parathyroid adenoma; sign of bone remineralization and decreased calcium absorption. World J Surg $24: 1323$ $\sim 1329,2000$.

17）石田常博, 横江隆夫, 泉雄 勝 : 上皮小体腫瘍の全国集計 (1980 1989 年度症例). 内分泌外科 $8: 37 \sim 45,1991$.

18）湊 栄治, 寺邊政宏, 小池 宏, 他: 11 年後に局所再発し た上皮小体癌の 1 例. 日臨外 $59: 2000 \sim 2004,1998$.

原稿受付 : 平成 14 年 5 月 2 日

原稿採択 : 平成 14 年 7 月 3 日

別刷請求先：楯谷智子

厂524-8524 守山市守山5-4-30 滋賀県立成人病センター耳鼻咽喉科 